\title{
Case 2603
}

\section{GRYLLACRIDOIDEA Stål, 1874 (Insecta, Orthoptera): proposed precedence over STENOPELMATOIDEA Burmeister, 1838}

\author{
K. H. L. Key \\ Division of Entomology, C.S.I.R.O., G.P.O. Box 1700, Canberra, A.C.T. 2601, \\ Australia
}

\begin{abstract}
The purpose of this application is to conserve the name GRYLLACRIDOIDEA Stål, 1874 (first used at the superfamily level by Zeuner, 1935) by giving family-group names based on Gryllacris Audinet-Serville, 1831 precedence over family-group names based on Stenopelmatus Burmeister, 1838.
\end{abstract}

1. Burmeister $(1838$, p. 720$)$ published the name STENOPELMATIDAE, type genus Stenopelmatus Burmeister, 1838 (p. 720 ), and 36 years later Stål $(1874$, p. 4) published GRYLLACRIDIDAE with type genus Gryllacris Audinet-Serville, 1831 (p. 138). For some reason the priority of STENOPELMATIDAE was completely overlooked until Kevan (1982), all authors proceeding on the tacit assumption that priority rested with GRYLLACRIDIDAE. However, this misapprehension gives rise to nomenclatural consequences only when Stenopelmatus and Gryllacris are included in the same family-group taxon. This has happened in two ways.

2. A number of authors downgraded STENOPELMATIDAE and GRYLLACRIDIDAE to subfamily rank within a single family, for which they invariably used the name GRYLLACRIDIDAE. Examples are: Hubbell (1936, pp. 24-25); Karny (1937, pp. 35-36; the principal world authority on the group); Zeuner (1939, pp. 59-64; a leading insect palaeontologist); Borror \& White (1970, p. 82); and Daly, Doyen \& Ehrlich (1978, p. 82).

3. On the other hand, Zeuner (1935, p. 108) retained family rank for the two taxa and included them in a superfamily GRYLLACRIDOIDEA (the correct form of his 'Gryllacridioidea'). This name, or its equivalent (e.g. 'Gryllacridides' Beier, 1955 (pp. 240-242)), has been used in at least the following major compendia (for details see references).

1949. Traité de Zoologie (Ed. Grassé) - the major work in the French language, p. 651.

1951. Faune de France, p. 170.

1953. Traité de Paléontologie (Ed. Piveteau), p. 469.

1955. Bronns Klassen und Ordnungen des Tierreichs - one of the major works in the German language, p. 240.

1955. South African Animal life (Eds. Hanström, Brinck \& Rudebeck), p. 285.

1970. The Insects of Australia (C.S.I.R.O.), p. 331.

1977. Imms' General Textbook of Entomology (Ed. 10) - perhaps the best-known textbook of entomology in English, p. 544.

1978. Biogeography and Ecology of Southern Africa (Ed. Werger), p. 744.

The authors of the relevant contributions in the above works include the leading authorities L. Chopard, M. Beier, D. Laurentiaux and O. W. Richards. In addition, 
GRYLLACRIDOIDEA has been used in various smaller works on the Orthoptera, including those of Kevan (1977, pp. 22 \& (19)) and of Rentz (1980, p. 49; 1986, p. 232).

4. Kevan (1982,p. 354) introduced the superfamily name STENOPELMATOIDEA, stating merely '(=Gryllacridoidea)'. Vickery \& Kevan (1983, pp. 311, 313) sought to justify this substitution by pointing out the priority of the name STENOPELMATIDAE (1838) over GRYLLACRIDIDAE (1874) - these names being 'coordinate' with the corresponding superfamily names. While they cited the International Code as their authority, they ignored those provisions of the Code that explicitly limit the operation of the Principle of Priority, i.e. the Preamble, Article 23b, and Article 79. The circumstances of this case bring it very clearly within the scope of those provisions.

5. To accept STENOPELMATOIDEA (or any other superfamily name) as a substitute for GRYLLACRIDOIDEA would be to overturn the extensive usage of 50 years of work on the systematics, palaeontology, and biology of the Orthoptera-Ensifera; in the interest of a name wholly unused prior to 1982 . The situation is particularly serious because of the high categorical rank of the names concerned. This sort of name-changing does nothing for science, confuses the users of the names and conflicts with relevant provisions of the Code: it is quite clear that (in the terms of Article 23b) 'the application of the Principle of Priority [in this case] would disturb stability or universality or cause confusion'. Although presumably Kevan did not 'consider' this to be the case, it is open to a later author to come to that conclusion. Accordingly, I now request the International Commission on Zoological Nomenclature to conserve the name GRYLLACRIDOIDEA. In doing so, I note that 'use of a name contrary to the purpose of the Principle of Priority [i.e. of STENOPELMATOIDEA since 1982] . . . will not be accepted as usage unless the Commission is satisfied that special circumstances justify such acceptance' (Art. 79c (2)(i); and that 'when a case is under consideration by the Commission, existing usage is to be maintained ...' (Art. 80a), 'existing usage' being defined as 'the most common current usage' (Art. 80c).

6. It remains to consider what is the most appropriate means for conserving GRYLLACRIDOIDEA. As mentioned above, some authors have included subfamilies STENOPELMATINAE and GRYLLACRIDINAE in a family GRYLLACRIDIDAE. For these reasons the ruling should not be restricted to the superfamily level; it is of course not possible to suppress any of the family-group names while retaining Gryllacris and Stenopelmatus (which are both already on the Official List of Generic Names).

7. The International Commission on Zoological Nomenclature is accordingly asked:

(1) to use its plenary powers to rule that the family-group name GRYLLACRIDIDAE Stål, 1874 and other family-group names based on Gryllacris Audinet-Serville, 1831 are to be given precedence over STENOPELMATIDAE Burmeister, 1838 and other family-group names based on Stenopelmatus Burmeister, 1838, whenever those genera are placed together in any taxon of the family group;

(2) to place the following names on the Official List of Family-Group Names in Zoology;

(a) GRYLLACRIDIDAE Stål, 1874 (type genus Gryllacris Audinet-Serville, 1831), with the endorsement that it and other family-group names based on Gryllacris are to be given precedence over STENOPELMATIDAE Burmeister, 1838 (type genus Stenopelmatus Burmeister, 1838) and other family-group names based on Stenopelmatus whenever those genera are placed together in any taxon of the family group; 
(b) STENOPElMATIDAE Burmeister, 1838 (type genus Stenopelmatus Burmeister, 1838), with the endorsement that it and other family-group names based on Stenopelmatus are not to be given priority over GRYLLACRIDIDAE Stål, 1874 (type genus Gryllacris Audinet-Serville, 1831), and other family-group names based on Gryllacris whenever those genera are placed together in any taxon of the family group.

\section{References}

Audinet-Serville, J. G. 1831. Revue méthodique des Insectes de l'ordre des Orthoptères. Annales des Sciences Naturelles (Zoologie), 22: 28-65, 134-167, 262-292.

Beier, M. 1955. Buch 6, Embioidea und Orthopteroidea. Bronns Klassen und Ordnungen des Tierreichs, vol. 5, part 3.585 pp. Leipzig.

Borror, D. J. \& White, R. E. 1970. A Field Guide to the Insects of America North of Mexico. 404 pp. Boston.

Burmeister, H. 1838. Handbuch der Entomologie, vol. 2, part 2. pp. 397-1050. Berlin.

Chopard, L. 1949. Ordre des Orthoptères. In Grasse, P.-P. (Ed.), Traité de Zoologie, vol. 9. 1117 pp. Paris.

Chopard, L. 1951. Orthopteroides. Faune de France, vol. 56.359 pp. Paris.

Chopard, L. 1955. Orthoptera Ensifera. Pp. 266-300 in Hanström, B., Brinck, P. \& Rudebeck, G. (Eds.), South African Animal Life, vol. 2.576 pp. Stockholm.

Daly, H. V., Doyen, J. T. \& Ehrlich, P. R. 1978. Introduction to Insect Biology and Diversity. 564 pp. New York.

Hubbell, T. H. 1936. A monographic revision of the genus Ceuthophilus (Orthoptera, Gryllacrididae, Rhaphidophorinae). Publications of University of Florida (Biological Science Series), vol. 2 , no. $1.551 \mathrm{pp}$.

Karny, H. H. 1937. Orthoptera Fam. Gryllacrididae Subfamiliae Omnes. Genera Insectorum, vol. 206. 317 pp. Brussels.

Kevan, D. K. McE. 1977. The higher classification of the orthopteroid insects: a general view, pp. 1-31; and Appendix (26 pp.): Suprafamilial classification of 'orthopteroid' and related insects; a draft scheme for discussion and consideration. Lyman Entomological Museum and Research Laboratory, Memoir no. 4. 52 pp. + Appendix.

Kevan, D. K. McE. 1982. Orthoptera. Pp. 352-379 in Parker, S. P. (Ed.), Synopsis and Classification of Living Organisms, vol. 2. 1232 pp. New York.

Key, K. H. L. 1970. Orthoptera (Grasshoppers, locusts, crickets). Pp. 323-347 in The Insects of Australia. A Textbook for Students and Research Workers. 1029 pp. C.S.I.R.O., Melbourne.

Laurentiaux, D. 1953. Classe des insectes (Insecta Linné 1758). Pp. 397-527 in Piveteau, J. (Ed.), Traité de Paléontologie, vol. 3. 1063 pp. Paris.

Rentz, D. C. F. 1978. Orthoptera. Pp. 733-746 in Werger, M. J. A. (Ed.), Biogeography and Ecology of Southern Africa, vol. 2 (pp. 663-1439). The Hague.

Rentz, D. C. F. 1980. A new family of ensiferous Orthoptera from the coastal sands of southeast Queensland. Memoirs of the Queensland Museum, 20: 49-63.

Rentz, D. C. F. 1986. The Orthoptera family Cooloolidae, including description of two new species and observations on biology and food preferences. Systematic Entomology, 11: 231-246.

Richards, O. W. \& Davies, R. G. 1977. Imms' General Textbook of Entomology, Ed. 10, vol. 2. $1354 \mathrm{pp}$. London.

Stål, C. 1874. Recensio Orthopterorum. Revue Critique des Orthoptères décrit par Linné, De Geer et Thunberg, vol. 2 [8 pp.]+21 pp. Stockholm.

Vickery, V. R. \& Kevan, D. K. McE. 1983. A Monograph of the Orthopteroid Insects of Canada and Adjacent Regions. Lyman Entomological Museum and Research Laboratory, Memoir no. 13 , vol. 1.679 pp.

Zeuner, F. E. 1935. The recent and fossil Prophalangopsidae (Saltatoria). Stylops, 4: 102-108.

Zeuner, F. E. 1939. Fossil Orthoptera Ensifera. 321 pp. London. 


\section{$2 \mathrm{BHL}$ Biodiversity Heritage Library}

Key, Kenneth H L. 1989. "Case 2603 Gryllacridoidea Stål, 1874 (Insecta, Orthoptera): proposed precedence over Stenopelmatoidea Burmeister, 1838." The Bulletin of zoological nomenclature 46, 25-27. https://doi.org/10.5962/bhl.part.475.

View This Item Online: $\underline{\text { https://www.biodiversitylibrary.org/item/44487 }}$

DOI: https://doi.org/10.5962/bhl.part.475

Permalink: https://www.biodiversitylibrary.org/partpdf/475

\section{Holding Institution}

Natural History Museum Library, London

\section{Sponsored by}

Natural History Museum Library, London

\section{Copyright \& Reuse}

Copyright Status: In copyright. Digitized with the permission of the rights holder.

License: http://creativecommons.org/licenses/by-nc-sa/3.0/

Rights: https://biodiversitylibrary.org/permissions

This document was created from content at the Biodiversity Heritage Library, the world's largest open access digital library for biodiversity literature and archives. Visit BHL at https://www.biodiversitylibrary.org. 